\title{
IMPACT OF ADVERTISING: END USER PERSPECTIVE
}

\author{
Masroor Khanam* \\ Akbar Ali ${ }^{* *}$
}

\begin{abstract}
The purpose of this study is to investigate the end user perspective of advertising in Pakistan. This involves exploring and examining the consumer feedback about advertising from multiple dimensions. In this regard, survey was done for the current developments in literature so far, in order to discover a general pattern of consumer attitude that has been developing over time. This leads us to the realization that the advertising has been radically changing since its beginning with the change in literature. Advertisers communicate with consumers through advertising, public relations, direct marketing, interactive/Internet marketing, sales promotion etc. organizations must use all available communication tools to communicate consumer and to create awareness about the need of consumer. Advertising is used to create awareness for products and services. Advertisers should know the needs of consumers, target audience, their culture, likes and dislikes. Advertising create feelings and satisfaction in consumer's mind. Many food and beverage brands use advertising for the promotion of their products. Advergames have an advertisement for a product, service, or company and have become popular. Cultural frame work plays important role in advertising and consumer behavior. Music plays an imported role in advertising; it has recently attracted interest in marketing and consumer psychology. Music is key elements of the culture; it plays an important role in consumers' perceptions, moods, and in the theme of the advertisements.
\end{abstract}

Keywords: advertising, consumer, end-user, product, organization, marketing

\section{Introduction}

Advertisement is essential for life and consumers have usually similar behavior for the response of advertisement. ${ }^{1}$ Consumers are first impressed by advertisements. Behavior of customer is considered vital towards advertising according to O'Guinnetal. ${ }^{2}$

Contact with customer plays vital role and sometimes it is difficult to analyze the behavior of end user. Consumers' behavior to ads in Social Network Sites is low. ${ }^{3}$ Brand

\footnotetext{
* Masroor Khanam, Ph.D., Assistant Professor, Federal Urdu University of Arts, Science and Technology, Abdul Haq Campus, Karachi

Akbar Ali, Ph.D., Dean, MIS National University of Science \& Technology Islamabad, NUST-PNEC.

${ }^{1}$ Shavitt, S., P. Lowrey and J. Haefner (1998). Public Attitudes Towards Advertising: More Favorable than You Might Think. Journal of Advertising Research, 38(4), (world advertising research , 1998), 7 - 22

${ }^{2}$ O'Guinn, Thomas C., Chris T. Allen, and Richard J. Semenik.Advertising.(Cincinnati, Ohio: South-Western College Publishing, 1998).

${ }^{3}$ Bang, H., Ross, S., \&Reio, T. G. From motivation to organizational commitment of volunteers in nonprofit sport organizations: The role of job satisfaction. Journal of Management Development, 32(1), (Emerald insight 2013), 96-112.
} 
attitude towards health is important. ${ }^{4}$ There is a relationship between socialization agents and product placement. ${ }^{5}$ The Impact of Videogame-induced affect and ad type on memory of n-game advertisements. ${ }^{6}$

Advertising is one of the best ways of selling products it is a vital part of life and people couldn't imagine their daily life without it. Advertising is a service to the community. However, in reality it has both its advantages and disadvantages. It makes our life more comfortable. Posters and advertisements are now in very different style and attract all people. Advergames, videos play an important role for marketing and marketing depends on advertisement. Advertising informs people about domestic products. Advertising helps in shopping to understand the use of products. Advertising guides consumer about products of every part of life.

According to Nishant's definition, ${ }^{7}$ advertising is a form of mass communication. Advertising is a very gigantic industry. Advertising conveys specific benefits for consumers. First off all, the advertising gives information to consumers about the worth, benefits, use of the product. Advertisements in the world catch the attention of consumers to buy products .Advertisements are published in newspapers, magazines, schools, and on billboards, posters TV, etc.

It is important for the advertisers to pay attention on the advertisement according to the product to attract the consumer. Personal feelings are also responsible along with the need of the consumers. Customers' thoughts and perception plays an essential role towards the success of any product campaign. ${ }^{8}$

Audience manner towards advertisements have been a researched area for long time. ${ }^{9}$ Public opinion research involves collecting information on the ideas, perceptions, attitudes and opinions of general public. Regardless of the objectives and intention of the advertisers if the observation and opinion of target consumers is not amenable or favorable all the efforts of the interested parties will be wasted. ${ }^{10}$ It is necessary to investigate consumers' attitudes, beliefs, values, benefits, and opinion about the usage

\footnotetext{
${ }^{4}$ Velez, J. A., Mahood, C., Ewoldsen, D. R., \& Moyer-Gusé, E. Ingroup Versus Outgroup Conflict in the Context of Violent Video Game Play: The Effect of Cooperation on Increased Helping and Decreased Aggression. Communication Research. Advance Online Publication.(2012)

/(journals.sagepub.com/doi/abs/10.1177/0093650212456202)

${ }^{5}$ Craig_Clay(2013),Socialization of Product Placements: How are emerging adults influenced by parents, peers, and media?( Texas Tech University ,2013)

${ }^{6}$ Dardis, F. E., Schmierbach, M., Sherrick, B., Waddell, F., \& Aviles, J., Kumble, S., \& Bailey, E. Adverwhere? Comparing the Effectiveness of Banner Ads and Video Ads in Online Video Games. Journal of Interactive Advertising, 16(2), (Accepted author version posted online: 06 Sep 2016, Published online: 13 Sep 2016), 87-100. Accepted author version posted online: 06 Sep 2016, Published online: 13 Sep 2016 7Best Thoughts and Quotes of the World: Lead an Inspired Life By Shashikant Nishant Sharma, https://edupediapublications.org/Amazon.com

${ }^{8}$ Bond, G. and Griggs, S. 'Group Discussion Attendance and Attitudes to TV Advertising', Journal of the Market Research Society 38(2): (International Journal of Market Research, 1996), 207-18.

${ }^{9}$ Mittal, B. (1994). Public assessment of TV advertising: Faint Praise and Harsh Criticism. Journal of Advertising Research, 34 (1), (Journal of advertising research, 1994 - go.galegroup.com 1998), 35-53.

${ }^{10}$ Ducoffe, R. H. (1996). "How Consumers Assess the Value of Advertising.Journal of Current Issues and research in Advertising 17, (Journal of Current Issues \& Research in Advertising, 1996), pp.1-18.
} 
and benefits of advertising from the perspective of advertisement policy makers, designers and marketers. This study mainly focuses on exploring the beliefs and attitudes that are used to form the opinion of general public towards advertisement in relationship with product information, publicity, benefits and the role of advertisement in the selection process of a product.

Behavior of the customers towards advertisements is important which actually decides their buying behaviors afterwards. The research results will be beneficial for the advertisement strategists from both domestic and international market to enhance the effectiveness of the advertisement design as per the general attitude/behavior of the customers by keeping in mind that how consumer understands publicity and advertisement.

\section{Literature Review}

By the very structure of information advertising is non-personal and by the very nature it is persuasive by known sponsors through a collection of media. ${ }^{11}$ Advertisements have become an integral part of today's consumer life. Consumers are bombarded daily with huge number of advertisements through a variety of media and there is a constant increase in the variety of media carrying advertisement messages (Krugmanetal 1994)2. ${ }^{12}$ In the recent past much research has focused on public attitude towards advertising (Polly and Mittal 1993)3. ${ }^{13}$ During past decades several researches have been made on public attitude towards advertising.

In Pakistan a few researchers have worked on the concept of public feelings towards advertising. ${ }^{14}$ Consumer attitude has been investigated and it varies according to usage. ${ }^{15}$ Gallup survey showed that majority of respondents liked advertisements because in their opinion advertisement was informative for them. In their assessment they used the tool of personal interviews over a large set of national probability sample. In few studies conducted in Romania and Bulgaria respondents believe in the informative value of advertising. ${ }^{16}$

Penny M. Simpson ${ }^{17}$ proposed unethical perceptions of the advertisement shown significance and negative effect. Sandage ${ }^{18}$, Rettieetal ${ }^{19}$ and Zhang ${ }^{20}$ suggested that use of

\footnotetext{
${ }^{11}$ Bovee, C.L., \&Arens, W. F. Contemporary Advertising.(Boston: Richard D. Irwin, Inc., 1992)

${ }^{12}$ Krugman, Dean M.; Leonard N. Reid.; Watson S. Dunn.; \& Barban M. Arnold. (Advertising: Its Role in Modern Marketing 8th ed. (Fort Worth: Dryden Press, 1994).

${ }^{13}$ Polly, R., \& Mittal, B. Here are the beef factors, determinants, and segments in consumer criticism of Advertising. Journal of Advertising, 57 (7), (www.Scholarhub.net 1993), pp.99-114.

${ }^{14}$ Usman, M., Ilyas,S., Hussain,M.F. and Qureshi,T.M. General Attitude towards advertising: Cultural influence in Pakistan. International Journal of Marketing Studies.Vol 2, No 2 (www.ccsenet.org/, 2010).

${ }^{15}$ Zanot, E. .Public Attitudes Toward Advertising. In H. Keith hount (Ed.), Advertising in a New Age,(Provo, Utah: American Academy of Advertising, 1981).

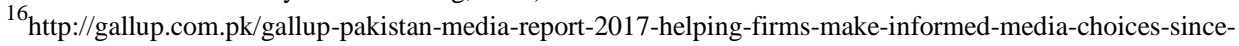
1979/ (accessed in Sept 2017)

${ }^{17}$ Penny M. Simpson, Gene Brown, Robert E. Wilding II. "The Association of Ethical Judgment of Advertising and Selected Advertising Effectiveness Response Variables" Journal of Business Ethics17:(Journal of Business Ethics 17: 125-136, 1998. ( 1998 Kluwer Academic Publishers.Printed in the Netherland 1998) pp. 125-136.
} 
interfering strategy in advertising can have negative effect on the audiences. ChungChuan Yang ${ }^{21}$ has established negative effects of advertising on student's thoughts towards advertising. He said that students in Taiwanese college considered advertising as wasteful of national resources. The students also have the same opinion that advertising is misleading and deceptive, $\operatorname{Reid}^{22}$ found that in advertising gender plays an important role.

Advertising approaches social and economic scope. UgurYavas ${ }^{23}$ Chung-Chuan Yang ${ }^{24}$ has found Taiwanese college students say that advertising helps a nation's economy; advertising supports competition and benefits consumers and raising their standards of living. Students consider advertising as an important source of fashion information and help them keep up with the products and services available in the market place. Beard ${ }^{25}$ repeated Larkin's study and found that college students distinguish advertising as performing an important economic role.

\section{Research Methodology}

Qualitative research methodology was used and based on review of literature.

Consumer Behavior was observed through research publications the work which has done. It is based on the review of the literature.

1. Advertisements are useful to find out the factors that influence consumer buying behavior. They are following:

2. Type of brand of a product.

3. How many times a consumer has watched an advertisement for the brand?

4. The selected brand is on sale.

5. The impact of income on purchase of the product.

6. Advertisement has a big influence on consumer behavior.

\section{Necessary Information}

1. Awareness (aided/ unaided)

\footnotetext{
${ }^{18}$ Sandage and Leckenby. (1980) Student Attitudes Toward Advertising: Institution vs. Instrument. Journal of Advertising (9:2 https //dio.org.1980)

${ }^{19}$ Rettie, R., Robinson, H., and Jenner, B. Does Internet Advertising Alienate Users? Paper presented at Academy of Marketing Conference, Title of the conference(KINGSTON BUSINESS SCHOOL Kingston University Occasional Paper Series No 52, 2013)

${ }^{20}$ Zhang, P. The Effect of Animation on Information Seeking Performance on the World Wide Web: Securing Attention or Interfering with Primary Tasks.Journal of Association for Information Systems (JAIS) (1:1), (Association for Information Systems Atlanta, GA, USA, 2000).

${ }^{21}$ Chung-ChuanYang."Taiwanese students' attitudes towards and beliefs about advertising" Journal of Marketing Communications, 6, (Pages 171-183 | Published online: 09 Dec 2010,2000),pp.171-183

${ }^{22}$ Reid, L. N., \&Soley L. "Decorative models and the readership of magazine ads".Journal of Advertising Research, 23,( 1983),pp.27-32.

${ }^{23}$ Nicholas J. Ashill, UgurYavas "Dimensions of Advertising Attitudes" Congruence Between Turkish and New Zealand Consumers, Marketing Intelligence \& Planning Vol. 23:4, (Online Publication, 2005),pp.340-349

${ }^{24}$ Chung-Chuan Yang (2000)" Taiwanese students' Attitudes Towards and Beliefs About Advertising” Journal of Marketing Communications,6(online publication, 2000),171-183

${ }^{25}$ E.W.T. Ngailnternet marketing research (1987-2000): a Literature Review and Classification
} 
2. Purchase timing

3. Consideration repealed set

4. Choice set

5. Belief dynamics

6. Individual awareness

7. Evaluation Product perceptions

8. Product preferences

9. Attitude

10. Compensatory

11. Non-compensatory Purchase Brand choice

12. Store choice

13. Quantity choice

14. satisfaction

15. Communications network

\section{Results}

Customers show preference about specific products, brands and companies. Consumer interest is important but motivation of consumers to purchase products depends upon their taste, need and pocket. Advertising plays important role in customers behavior and develop their mind to purchase product. Social media also generates profiles of the consumer and send messages and ads according to the choice of consumer. Face book and internet advertisers target all gender types according to their age, likes and dislikes. Television advertisers are successful because a large audience watches TV of all ages and gender and areas throughout the world. Mobiles or cell phones are also used for advertisements and they have targeted consumers.

\section{Discussion}

Consumer Behavior deals with the variety of phases a consumer. Consumer buys a product according his need, demands and Social Status. Sometimes individual does not buy because he/she has no requirement, income / budget / financial limits, taste. Consumers purchase products for many reasons, according to season, parties, formal and informal reasons. There are many reasons that control buying choice of a consumer that is also depends on their psychological, social, cultural and economic conditions. There are many sources of information for instance personal, commercial, public, and personal experiences, perception also plays an important role in influencing the buying decision of consumers.

Choice of a customer to buy a product may also depend on the different sources such as observation, messages, interpretation etc. A consumer buys something that attracts $\mathrm{him} /$ her the most. According to gender buying behavior is very different and also psychology, economic, social conditions responsible for it.

General point of view on accepting the end-user is not enough, and triangulation of speculative perspectives is essential. Three perceptions can be taken for end user, the end-user as a technology user, product user and consumer. The capability of media to 
bring direct feedback has motivated and improved rates for electronic media advertising such as, advertisements on TV channels, Internet posters and Internet searching. And it has increased end users choice and rating as well. It also has increased the printed forms for examples direct mail. Different lucrative channels coordinate the social networks of consumers. Consumers or end users response advertising and they are always ready to buy products based on good advertising. Public unreceptively scrutinize the world around it, and they learn new things consciously or unconsciously or may not be related to the current situation but they take it as future use. For a number of media types such as magazines and newspapers and other print publications, consumers acknowledge advertising because it provides them latest information.

Advertising has impact on the end user according to need and age group. Priorities are different through age. It also depends on brands of the products. A convincing advertising possibly affect consumer selection. It is important to understand the relations between brands and customer. Consumer, advertisement and brand are interlinked to each other for the best results. Advertising has become an indispensible means of communication with the market and it is used for the users of product. The importance of advertising develops gradually because brands depends on media for a variety of marketing aims such as growing sales, creating knowledge and awareness in the market. Advertising plays a very vital role in determining the shifting customs of society both nationally and internationally. Advertising has both the positive and negative effects on the end users.

Online shopping is done by effective advertising with behavioral attitude which focuses on specific user actions such as browsing history, site history, and buying actions.

"When we have clients who are thinking about Flash splash pages, we tell them to go to their local supermarket and bring a mime with them. Have the mime stand in front of the supermarket, and, as each customer tries to enter, do a little show that lasts two minutes, welcoming them to the supermarket and trying to explain the bread is on aisle six and milk is on sale today. Then stand back and count how many people watch the mime, how many people get past the mime as quickly as possible, and how many people punch the mime out. That should give you a good idea as to how well their splash page will be received." - (Jared Spool $)^{\mathbf{2 6}}$

"Consider the decline in the quality and consistency of user interfaces. I look at the hideous UIs on many commercial applications and it's obvious the interface was slapped together just so that the design tool would crank out the code for handling user events. The code was finished, but the barely capable UI went out the door with just a little polish."- (TomYager, "Ahead of the Curve" Columnist, InfoWorld 2006) ${ }^{27}$

\footnotetext{
${ }^{26}$ Web Anatomy: Interaction Design Frameworks that Work 1st Edition by Robert Hoekman Jr. (Author), Jared Spool (Author)

${ }^{27}$ (TomYager, "Ahead of the Curve" Columnist, InfoWorld 2006)
} 
"On a contract assignment, the owner of a small industrial control software company told me "We do not want our (end-user) documentation to be too clear. We make a lot of money doing training."- ${ }^{28}$

Focus on how the end-user customers perceive the impact of your innovation - rather than on how you, the innovators, perceive it. ${ }^{29}$

I think this is a terrific move where a large end-user supports the technology. ${ }^{30}$

"People react positively when things are clear and understandable." 31

The above quotations can easily be expressed the feelings of the end user and the advertisers. These are the expressions of the famous people of the world of every field of life. So we can say that the effective advertising attracts a large number of audiences with different minds, fields, age, gender and interests and behavior of end users proves the good or bad advertising impact. Impact of advertising increases the production.

\section{Conclusions}

Advertisements encompass major impact on public as well as product selections and in general awareness about products. The advertisements impact on both the gender evenly but choice for products depend on different factors and end users perspective show variability. As we know that the end user is the entity who uses the product after its production. This term shows two types of users one who need a product for use and users who could use the same product for progress reasons.

Economical, psychological cultural reasons are responsible for the use of a product. An individual buy anything according to the economical, psychological and cultural status. An individual buy products due to certain reasons, according to season, parties, formal and informal reasons. There are many reasons that influence buying behavior of a consumer depends on their psychological, social, and economic conditions.

Introduction of new products usually based on the behavior and response of the end users and consumers. Broachers and manuals provide information to the end user which also helps to the producer to develop product through feedback of the consumers. Keeping records of the consumer's opinions also play an important role for the product improvement, marketing and development.

A lot of methods are used to recognize the needs of end user. Opinions and participation on a product is the major instrument for the development. The common perceptive is that the more practical the product demonstration the better the result. Some end user needs Brands specifically and they do not compromise any other product.Good advertising can

\footnotetext{
${ }^{28}$ Jared Spool\& Robert Hoekman Jr Web Anatomy: Interaction Design Frameworks that Work 1st Edition

${ }^{29}$ Ibid.

${ }^{30}$ Ibid.

${ }^{31}$ Ibid.
} 
change the product brand of end user. End users need products and services to carry out the ideas related to their demand. Effective advertising has very lasting impact on end user. Nowadays people have more independence and decision making power than the previous generations and more educated. End users are also depending on online marketing and they are louder for their comments about a product.

Brand consciousness achieves a number of points of views to boost up sales in the market. A brand awareness movement should be flexible enough to rise with the demand of end-user. The corporation should search for to build customer awareness, uphold its website. Web services now generating new business enterprises and returns facilities for internet companies and end users. Companies have rising technological competence by which they get information about web users. And due to marketing consumers attract them. Internet service sources directly show advertisements for related product for the consumer's first choices.

Advertising campaigns are capable to target the user for the product skillfully. Nowadays if a user wants to buy through online the user just click the name of the product and through IP address receives so many ads to select right product. Social media is also a targeted advertising. For example, on Face book when consumer likes clothing pages then the consumer starts receiving pages of that product related to their demand and selection. This permits advertisers to target definite consumers as they can state cities and interests to their needs.

Targeted advertising has many advantages for consumers because advertisers are able to successfully attract the consumers. Using the consumers purchasing and browsing patterns this enables ads to be more obvious and useful for customers. Direct and effective delivery of the product to the end users enhances the desire of the end users. Effective advertising increased the desire of the consumers. For the representation of the product and improved market the advertiser is supposed to have to keep some following points in mind. The advertisements should be based on diversity and certainty. There should be more stress on quality not on glamour and cost. An effective advertisement should be broadcasted only 3 or 4 times in a day. The advertisers should understand one thing that an advertisement expresses nonstop information about the product instead of the fashion and style of the models. The advertisers must tell the price of product for the consumer's convenience. In addition, high frequency of advertisements in the prime time put up them unproductive and consumers do not show interest in the information of the particular product. Primetime is not always best for advertisements as well during the drama the advertisement should not be broadcasted because sometimes it creates wrath and disgust in the viewer's brain and heart for that particular product. The quality of advertisements must be attractive and high-quality as it keeps huge impression on the consumers mind. It is also a significant feature that more prize ideas do not hold backed the consumers to buy the goods if the quality is not good. As we know advertising is a form of communication which is used to convince a definite group of public to buy some new things. Advertising is considered as a chief and important constituent for the economic growth of society. Advertising is typically a paid form of exposure by sponsor through a range of media such as television, radio advertisement, outdoor advertising, newspaper, magazine mail, blogs, websites and text messages. Advertising became a 
source of leadership for consumers in $20^{\text {th }}$ century it was not only a source of direction for buying but also became part of society. Consumers buying behavior is very important and has space in the advertising effectiveness. Mainly consumers buying behavior is influenced by liking and disliking of the advertisement of the product. Advertising may have a negative, unintentional or intentional influence on consumers' buying tendencies. in fact advertising has a strong prospective on changing communal values, as well buying behaviors through influencing cultural values. Advertising could guide a customer to desire objects over ethically and generally oriented options and enhances competition. The most important aim of advertising is to provide something new, creative and useful benefits of brand loyalty and image building of the product. The accomplishment of advertising field has been acknowledged as a universal feature that advertising plays a very influencing task in the consumers' behaviors. Due to the impact of advertising, the advertisers have to follow the code of ethics, during the advertising of the products. The rationale of advertising should be the guidance of consumer not bothering and threatening by pushing forcefully to buy that product. Appropriate and successful advertising help the marketers to improve brand image and increase in demand in the marketplace. Effective advertising is the influence and liking or disliking attitude of consumer towards a particular product or advertising. There are many factors in advertising which provide changing the consumers' buying behavior such as brand image, expressiveness behavior of celebrities. All these features are the genuine providers towards the impact of advertising on consumers buying behavior.

\section{References}

Alwitt, L. F. and Prabhaker, P. R. "Identifying Who Dislikes Television Advertising: Not By Demographics Alone. Journal of Advertising Research (An Academic publisher, 1994)(34:6), pp.17-29.

Andrews, J. C. (1989). The Dimensionality of Beliefs Toward Advertising in General. Journal of Advertising, 18(1), 26-35.

Andrews, J.C., Durvasula, S. and Netemeyer, R.G. "Testing the cross-national applicability of US and Russian advertising belief and attitudes measures", Journal of Advertising, Vol. 23 No.1,(Research Gate, 1994) pp. 71-82.

Bang, H., Ross, S., \&Reio, T. G. From motivation to organizational commitment of volunteers in nonprofit sport organizations: The role of job satisfaction. Journal of Management Development, 32(1), (Online Publication 2013)96-112.

Bond, G. and Griggs, S. 'Group Discussion Attendance and Attitudes to TV Advertising', Journal of the Market Research Society 38(2):

(https://doi.org/10.1177/147078539603800301, 1996), 207-18.

Bovee, C.L., \&Arens, W. F. Contemporary Advertising. Boston: Richard D. Irwin, Inc. 
Chung-Chuan Yang (2000)" Taiwanese students' attitudes towards and beliefs about advertising" Journal of Marketing Communications, (https://doi.org/10.1080/13527260050118667, 1992).6 171-183

Craig_Clay(2013),Socialization of product placements: How are emerging adults influenced by parents, peers, and media?

Dardis, F. E., Schmierbach, M., Sherrick, B., Waddell, F., \& Aviles, J., Kumble, S., \& Bailey, E. (2016).Adver-where? Comparing the effectiveness of banner ads and video ads in online video games. Journal of Interactive Advertising, 16(2), 87-100.

Ducoffe, R. H. (1996). "How Consumers Assess the Value of Advertising." Journal of Current Issues and research in Advertising 17, pp. 1-18.

Gallup Organization (1959). A Study of Public Attitudes Towards Advertising. Princeton: Princeton University Press.

Jared Spool\& Robert Hoekman Jr Web Anatomy: Interaction Design Frameworks that Work 1st Edition

Krugman, Dean M.; Leonard N. Reid.; Watson S. Dunn.; \&Barban M. Arnold. (1994). Advertising: Its Role in Modern Marketing 8th ed. Fort Worth: Dryden Press.

Krugman, Dean M.; Leonard N. Reid.; Watson S. Dunn.; \&Barban M. Arnold. (1994). Advertising: Its Role in Modern Marketing 8th ed. Fort Worth: Dryden Press.

Mittal, B. (1994). Public assessment of TV advertising: Faint praise and harsh criticism. Journal of Advertising Research, 34 (1), 35-53.

Nishant Shashikant, Best Thoughts and Quotes of the World: Lead an Inspired Life, https://edupediapublications.org/Amazon.com

Nicholas J. Ashill, UgurYavas "Dimensions of advertising Attitudes" Congruence between Turkish and New Zealand consumers, Marketing Intelligence \& Planning Vol. 23 No. 4, 2005pp. 340-349

O’Donohoe, S. (1995) 'Attitudes to Advertising: A Review of British and American Research', International Journal of Advertising 14(3): 245-61.

O’Guinn, Thomas C., Chris T. Allen, and Richard J. Semenik.(1998).Advertising. Cincinnati, Ohio: South-Western College Publishing.

Penny M. Simpson, Gene Brown, Robert E. Wilding II (1998) “The Association of Ethical Judgment of Advertising and Selected Advertising Effectiveness Response Variables" Journal of Business Ethics 17: pp. 125-136.

Polly, R., \& Mittal, B. (1993). Here are the beef factors, determinants, and segments in consumer criticism of Advertising. Journal of Advertising, 57 (7), 99-114. 
Reid, L. N., \&Soley L. (1983) "Decorative models and the readership of magazine ads".Journal of Advertising Research, 23, 27-32.

Reid, L.N. and Soley, L.C. (1982) 'Generalized and Personalized Attitudes Towards Advertising's Social and Economic Effects', Journal of Advertising 11(3): 3-7.

Rettie, R., Robinson, H., and Jenner, B. .Does Internet Advertising Alienate Users?. Paper presented at Academy of Marketing, 2001

<http://www.kingston.ac.uk/ bs_s520/images/rettrob.pdf> (28/05/2015)

Rettie, R., Robinson, H., and Jenner, B. Does Internet Advertising Alienate Users?. (2001). Paper presented at Academy of Marketing Conference

Sandage and Leckenby. (1980) Student Attitudes Toward Advertising: Institution vs. Instrument. Journal of Advertising (9:2)

Sandage, Charles H., \& John, Lackenby. (1980). Student attitudes toward advertising: institution vs. instrument. Journal of Advertising, 9, 29-32.

Shavitt, S., P. Lowrey and J. Haefner (1998). Public Attitudes Towards Advertising: More Favorable than You Might Think. Journal of Advertising Research, 38(4), 7 - 22.

Usman,M., Ilyas,S., Hussain,M.F. and Qureshi,T.M.(2010). General Attitude towards advertising: Cultural influence in Pakistan. International Journal of Marketing Studies.Vol 2, No 2 (2010).

Velez, J. A., Mahood, C., Ewoldsen, D. R., \& Moyer-Gusé, E. (2012).Ingroup versus outgroup conflict in the context of violent video game play: The effect of cooperation on increased helping and decreased aggression. Communication Research. Advance online publication.

Zanot, E. .Public Attitudes Toward Advertising.. In H. Keith hount (Ed.), Advertising in a New Age,. Provo, Utah: American Academy of Advertising, 1981.

Zanot, E. .Public Attitudes Toward Advertising.. In H. Keith hount (Ed.), Advertising in a New Age,. Provo, Utah: American Academy of Advertising, 1981.

Zhang, P. .The Effect of Animation on Information Seeking Performance on the World Wide Web: Securing Attention or Interfering with Primary Tasks,. Journal of Association for Information Systems (JAIS) (1:1), 2000.

Zhang, P.(2000) .The Effect of Animation on Information Seeking Performance on the World Wide Web: Securing Attention or Interfering with Primary Tasks,. Journal of Association for Information Systems (JAIS) (1:1) 